\title{
Cooperative marketing alliances for new products commercialization as an entrepreneurial strategy: An analytical-comparative study of football industry
}

\author{
Mehdi Salimi ${ }^{1}$, Hadi Zarea ${ }^{1}$ and Datis Khajeheian ${ }^{2 *}$ \\ ${ }^{1}$ Entrepreneurship Management, Faculty of Entrepreneurship, University of Tehran, Iran. \\ ${ }^{2}$ Media Management, University of Tehran Faculty of Management, University of Tehran, Gisha Bridge, Tehran, Iran.
}

Accepted 28 October, 2011

\begin{abstract}
Marketing of new products as an important part of the commercialization process, plays a critical role in the success of developer companies. Most new products fail, and in sequence cause the company not to reach the financial and marketing aims. The paper concentrates on cooperative marketing alliances as a successful approach to commercialization of new products, by studying the Iranian Football Premier League as a context for cooperative marketing alliances among football clubs and business enterprises. Popularity of football clubs has been mentioned as a business platform, for commercialization and marketing of new products, not just by sponsorship, but by involvement of the club in marketing and even some production processes. The paper concentrates on sponsorship status in Iran and measures the success of this practice in clubs that participated in the Iranian Premier League 2008 to 2009. For this purpose, the contract duration, validity and payment on promise have been measured. Results show that sponsorship is usually very short term and supports only a small bulk of club costs. The reliance on governmental aids and unprofessional managers offers, are the main reasons for this failure. Then the structure of marketing in some pioneering football clubs studied as a benchmark for success. In conclusion, researchers suggest the promotion to co-marketing as a strategic alliance between football clubs and sponsors, so that mutual benefit can help football clubs to cover a greater part of their costs and have better usage from their equities, and help the business enterprise to enjoy from popularity of football clubs to exploit the market potential. Study results show that cooperative marketing may offer an entrepreneurial approach to new product commercialization, and will promote the marketing abilities of football clubs.
\end{abstract}

Key words: New product commercialization, sport marketing, cooperative marketing, Iranian Premier League, alliance, football management.

\section{INTRODUCTION}

Iranian Professional League began in 2001 to 2002 as a try to heightening professionalism in national football. One of the main goals of the league was transformation of governmental and public identity of Iranian clubs to the private and professional status. Unfortunately after eight years, still public and industrial clubs (which belongs to Government) reign on the national football and private

${ }^{\star}$ Corresponding author. E-mail: datiskh@ut.ac.ir. Fax: +9821 44252936. Tel: +98912 1908648 . clubs fight to survive. The most important problem bothering private clubs and even public ones is financial straits. Most of them rely heavily on governmental aids, solely because they lack sufficient marketing knowledge to use their equity as a football club. The reason underlying this dysfunction is probably the incomplete evolution towards a professional and widespread football management system. Almost none of Iranian clubs enjoys an updated marketing department, aware of updated revenue models. In broader term, almost none of them enjoy a football management system at all. It has been said that the only serious interaction between 
Iranian clubs and market is nothing but players transfer, and sponsorship. In recent years, some clubs tried to improve their financial status by some particular techniques, such as trading players or going under cover of some industries; however, these cannot ease the pain solely. So, it seems that designing and conducting of a research with a quest for the efficiency and usefulness of these practices is necessary. This research tries to inquire the revenue models of Iranian clubs and explore how this can do better for advancement of whole Iranian football.

\section{LITERATURE REVIEW}

\section{New product commercialization}

Kotler et al. (1999: 604) define new product development as the development of original products, product improvements, product modifications and brands through the firm's own R\&D efforts. They believe that commercialization is the final step in new product development. Zarea (2011) argues that mostly, commercialization fails because of the unsuitable marketing strategy or inefficient implementation. This is exactly what we need to concentrate on, that is how marketing strategy can be designed to produce results of success of product development. The marketing strategy development as Kotler et al. (1999: 614) described consists of some elements, one of the most important of them is to determine the target market. It seems that accessing the target market to offer new product is one of the main difficulties for ventures, so finding a way to penetrate the target market, especially for products affordable for youth and football clubs, can be facilitated if football clubs enter into marketing efforts, not just by embedding the product on the kit, but by participation in the marketing strategy, as a partner. Thus, it seems better to study a case, as success of cooperative marketing as an entrepreneurial strategy to reach the target market.

\section{The virtuous circle of the football club}

As Cherubini (2007) suggests, there is a virtuous cycle which shape core of business model for any football club(Shilbury et al., 1998). This virtuous cycle highly depend on success of club in competitions. This success results people interest consists of existing fans and potential fans and builds an excellent image for club which made its Brand more valuable and therefore, attract companies to exploit the image and penetrate to its fans market. This made revenues for club, both from people and companies. If club enjoys a premium management system, using this spending power will results club improvement and the cycle continues. Business model of each football club must take into account to serve two markets at the same time:
Business to consumer market (B2C) and business to business market (B2B). In order to develop the 'virtuous circle' properly, these markets should be mentioned in a synergistic way (Figure 1).

Of course this virtuous circle if not managed properly will fail and results a "vicious circle" that lead the club to the downturn phase which is not easy to escape.

\section{Football stakeholders}

Football has become the most popular sport of the world and due to its fans, the highest potential tool to gain profit. This potential caused many different players incorporate in the Football Business and competes or cooperates to each other to maximize their profit. So according to this presence, these stakeholders should be identified in order to manage them in the most appropriate way.

As shown in Figure 2, a football club is surrounded by a variety of people and organizations towards which it must show a positive attitude. These players include formal football organizations which define regulations and arrange tournaments (federation of football, league organization, etc.), the organizers of football events (stadium managers, equipment manufacturers, service providers, security providers, etc.), Commercial Sponsors, Media, Local Communities, Legal consultants and specially Football fans and Football players. This long list which can complete even more, show the complexity football executives should be faced with. Any effort to optimization of practices should mention all the stakeholders, otherwise may experience failure.

\section{Sponsorship}

Sponsorship is a business relationship between a provider of funds, resources or services and an individual, event or organization which offers in return rights and association that may be used for commercial advantage in return for the sponsorship investment (Shilbury et al., 1998). Today major sports properties rely very heavily on revenue and other benefits derived from sponsorship, so we cannot ignore this very important source of income. Instead we search for the better way to transaction between football club and commercial company. Highlighting the increasing importance of sport sponsorship as a marketing communications tool, Sergio Zyman, former Chief Marketing Officer at CocaCola criticizes the relationship between a sponsor and sports entity. In his opinion, the lack of synergy between sponsorship partners severely limits return on investment. He opines that the term "sponsorship" is partly to blame because it intimates a one-sided relationship in which the sponsor provides "financial assistance" and carries with it connotations of philanthropy, despite its commercial application. He even 


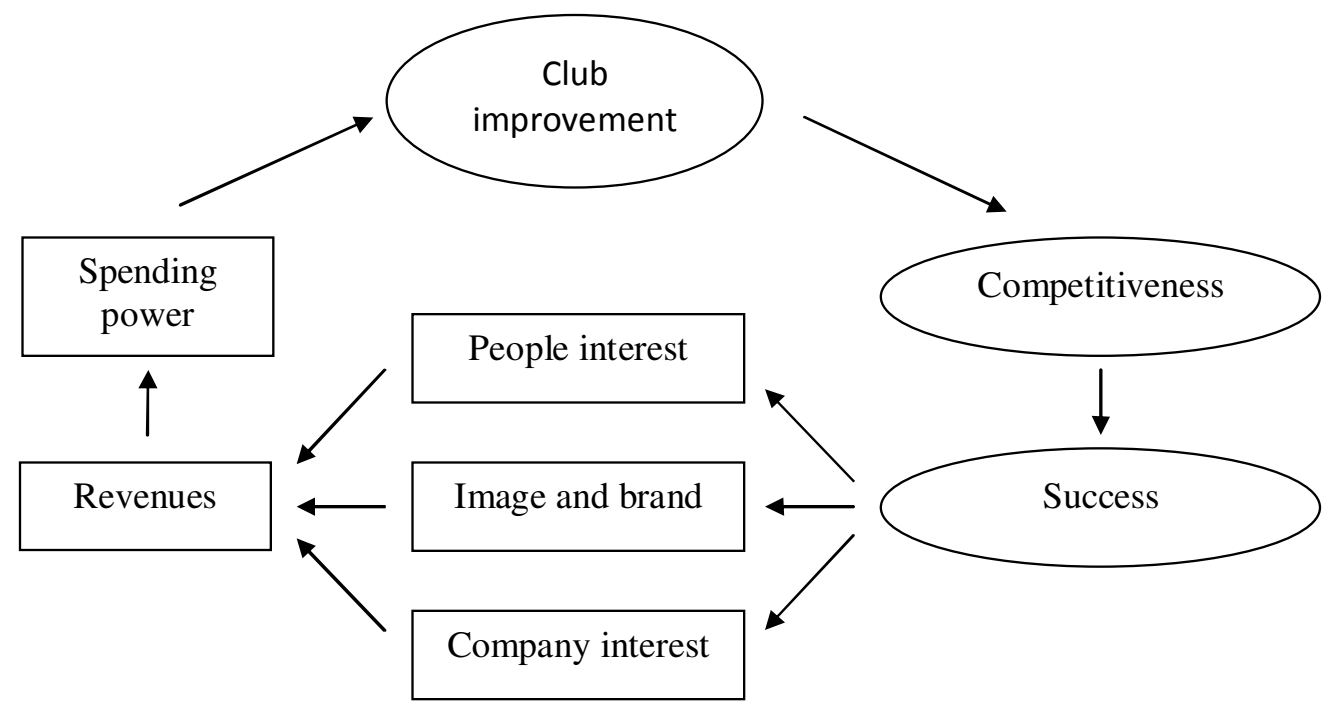

Figure 1. The virtuous circle of the football club (Cherubini, 2007).

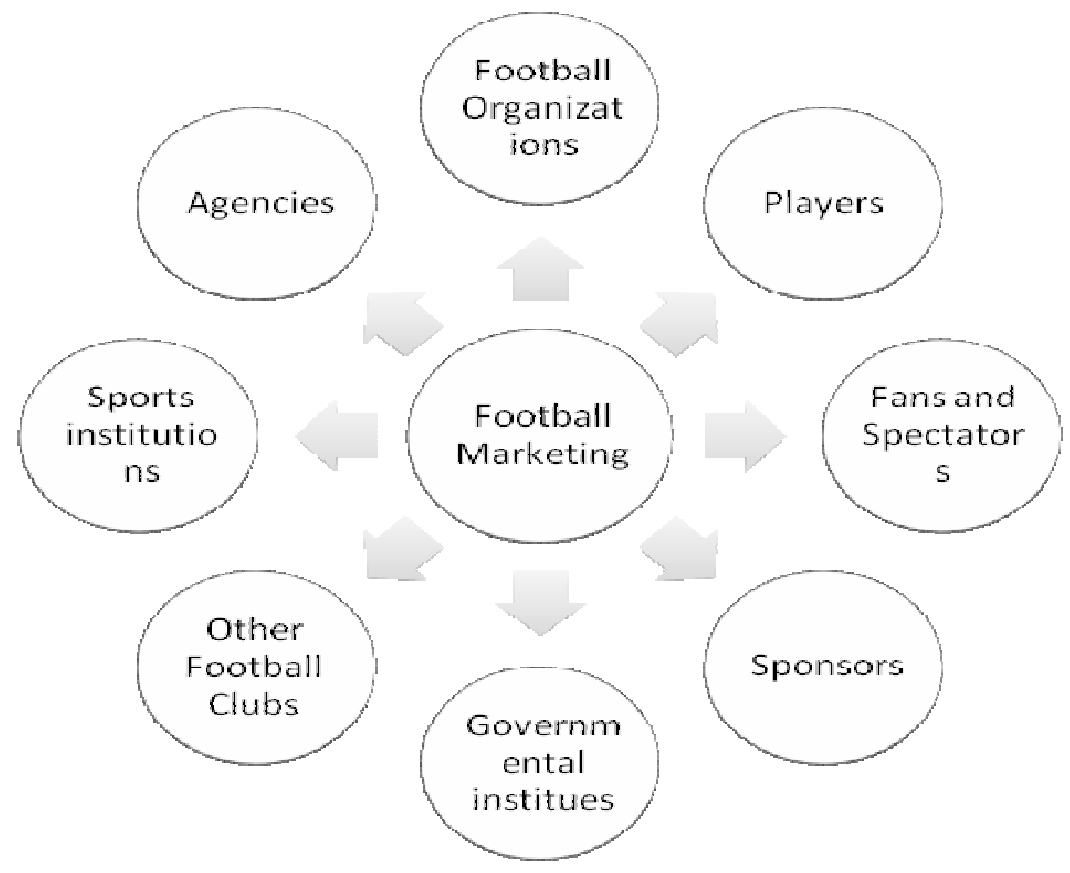

Figure 2. Football stakeholders (Shilbury et al., 1998).

suggests that the term "property utilization" should replace "sponsorship" in the marketing vernacular to better capture the commercial intent and responsibilities of those involved (Farrelly and Quester, 2005).

This critic on sponsorship practices can be pursuit on Iranian clubs truly. In spite of transaction between club and business, no marketing knowledge diffuse in club and the only benefit consists of the fund club receives. If wisely seen, this deal can promote the club marketing strategies and increase market knowledge of staff via deep interaction by sponsor. For example Samsung is most famous sponsor in season 2008 to 2009, by sponsorship clubs Esteghlal-e-Ahwaz and Bargh. These deals were only exclusive to Funds Company obligated, and nothing more. In our argument, these deals can be more profitable for both sides. The Sponsor can exploit all potential profitability of Club fame and club can promote its marketing knowledge and make money from 
its own potential helped by Sponsor skills.

Attending to high commercial potency of some Iranian clubs specially giants of capital, Persepolis and Esteghlal, implementation of optimized practices can results surprising awards. So in search of some best practices in world football and attending to our focus, we investigate the potential for sponsorship relationships to operate as a co-marketing alliance. We take a look on a sample of success in world class football and then turn to Iranian football to have an outlook about the level of potential exploitation.

\section{Real Madrid Case}

Real Madrid has evolved from the concept of sponsorship-partners that act as sponsors- to a system based on partnership - partners that add complementary values to the brand by generating synergies between the institutions that allow them both to conquer strategic markets. In this line, Real Madrid in 2005 signed sponsorship agreements with firms that were leaders in their markets at the national and international level. The team's main sponsor was the German company Siemens Mobile. This agreement involved the sponsorship of the soccer team, which carries the firm's advertising on the kit the players wear during matches, plus the development of joint businesses together, with Siemens providing the technological know-how and Real Madrid the contents. The Siemens shirt sponsorship was worth $\$ 17$ million.

Real Madrid then negotiated an improved shirt sponsorship deal with telecommunications company BenQ, worth 24 to $\$ 30$ million a season for four seasons from 2006 to 2007 onward. Apart from this main sponsorship agreement, Real Madrid had designed secondary packages consisting of sets of rights involving all the club's advertising vehicles. These provided huge exposure to brands associated with Real Madrid (Callejo and Forcadell, 2006).

\section{MATERIALS AND METHODS}

The content analysis has been used as the methodology of the research. As information in Iran football is not so clear and reliable, and mostly information offered in media are in paradox, the best way to get reliable information is content analysis which exploit facts from interviews, documents, official declarations and federation official statistics. Library research was used to gather information from world football and get knowledge from the practices of world class clubs, after which an analysis was performed by the researcher to get an adaptation sense for the Iranian context. The research is based on study of sponsorship practices and co-marketing techniques which is suitable for Iran context.

Firstly, we focus on the marketing part of football management system and study the business model which world class clubs follow and new marketing models. Then we turn to Iran context and look at the revenue model of domestic clubs and their efficiency. At the final step we concentrate on co-marketing as the core solution this paper offer and investigate if this could adapt to Iranian clubs.

\section{RESULTS}

\section{Sponsorship in Iran}

In contrast of what we mentioned in the case of Real Madrid or other professional football clubs, in Iranian clubs sponsorship is unable to play its critical role to fund clubs and success sponsors. Before we go deep and investigate the sponsorship of inefficient routines, the function of sponsorship in Iranian league from 2008 to 2009 should be considered.

During the Persian Gulf league, 2008 to 2009 among the 18 teams, only 2 teams had a fixed sponsor in all their matches (Esteghlal-e-Ahwaz and Bargh). These teams use Samsung Company as the main sponsor for all matches in the league and gain only $\$ 200,000$ as sponsorship contract. Compare it by the expenditures (for example $\$ 1,800,000$ Bargh), there is a huge gap between sponsorship income and costs of clubs. So we see sponsorship will not be a major financial Funder of clubs. After these teams, Persepolis was the other team which had only a sponsor during the league, but the sponsorship began from 6th week of the matches so Persepolis had no sponsor before. For the big giant of Iran sponsorship was not so successful too. Mary Brown signed the contract for $\$ 3,000,000$, but finally paid only $50 \%$. Mary Brown even forced the club to change the layout of suit to an unfamiliar horizontal stripe which never used before by club.

Other Iranian clubs use different sponsors during the season. Esteghlal-e-Tehran, another giant of Iranian football and surprising champion of season, used two different sponsors for two different period of league. Baazar-e-Mobl Iran signed sponsorship deal from 8th week for all the season, but from 17th week, contract revoked by $\$ 500,000$ and Baazar-e-Mobile Iran succeed it for another $\$ 500,000$. Sepasi carried Tabarrok on its kit for two matches and then changed sponsor. Pas-ehamedan signed Bic a sponsorship contract for $\$ 150,000$ which could be reached at the $\$ 500,000$, but the contract worked only 8 weeks. Another kind of sponsorship exists in the industrial clubs. These are clubs under ownership of some governmental industries or organizations. In these clubs, industrial owner fund budget and usually there is no serious problem for them. Tables 1 and 2 shows the difficulties of Iranian clubs in using sponsorship and some inefficiency in their interaction with commercial potential sponsors.

Also, the sponsorship in Iran has constrained to carry the sponsor's advertising on the kit and sometimes carries its brand in the conference room. The limited sponsor-club interaction in Iran creates no synergy for both sides and is a "lose-lose" game. So we can claim that sponsorship in Iran is an inefficient cycle. So this 
Table 1. Ownership of Iranian clubs engaged in premier league 2008 to 2009 by final ranking.

\begin{tabular}{cll}
\hline Final rank & Team & Ownership type \\
\hline 1 & Esteghlal & Public \\
2 & Zob Ahan & Industrial \\
3 & Mess-e-Kerman & Industrial \\
4 & Sepahan & Industrial \\
5 & Persepolis & Public \\
6 & Saba Ghom & Governmental \\
7 & Foolad & Industrial \\
8 & Paykan & Industrial \\
9 & Sepasi & Public \\
10 & Saipa & Industrial \\
11 & Rah Ahan & Public \\
12 & Pas Hamedan & Public \\
13 & Malavan & Public \\
14 & Esteghlal Ahwaz & Private \\
15 & Aboomoslem & Public \\
16 & Payam & Private \\
17 & Pegah (Damash) & Private \\
18 & Bargh Shiraz & Public \\
\hline
\end{tabular}

paper concentrates on the alternative approaches to better off the deal.

\section{CO-MARKETING}

Sport sponsorship can and should function as a better way which both sides can achieve jointly held objectives. In particular, co-marketing (cooperative marketing) activities, which are also carried out in other industries, can be very useful, although they represent a new challenge for football managers. In competitive landscape of today markets, strategic alliances are a familiar feature of the Marketing. These alliances which emphasize on such as joint product development and co-branding can become increasingly widespread.

According to Varadarajan and Cunningham (1995), "strategic alliances, a manifestation of inter-organizational cooperative strategies, entail the pooling of skills and resources by the alliance partners, in order to achieve one or more goals linked to the strategic objectives of the cooperating firms" (Varadarajan and Cunningham, 1995). They note that a strategic alliance can be structured either as a distinct corporate entity in which alliance partners hold an equity position, or as a distinct interorganizational entity to which the organizational partners commit resources and skills without sharing equity in the relationship.

In sponsorship, both sides agree to share resources in the form of intangible assets, such as brand image and corporate reputation. Also both partners benefit from factors that directly impact alliance performance. Also, sponsorship relationships have the potential to develop into co-marketing alliances where the product, brand, or corporate image of the alliance partners "are marketed together as a system" (Varadarajan and Cunningham, 1995). Also, Bucklin and Sengupta (1993) highlight the need for partners to leverage the unique skills and resources each brings to the table as a way of creating a "more potent force in the marketplace" (Bucklin and Sengupta, 1993).

The potential for symbiotic exchange clearly exists in the sponsorship relationship, as resources critical to performance can be derived from the interplay between partners. This can involve sharing commercial wisdom, including knowledge about brand building, more tangible assets such as consumer and fan profiles and possibly less-tangible resources such as creativity. Marketers and performers of sport and art rely continuously on their creative talents, and sponsors have an opportunity to extract creative ideas from them in relation to brand building and communication strategies, including launches, new product, service design and development and so forth (Farrelly and Quester, 2005).

Co-marketing is a cooperation approach to marketing wherein products or services from one company are marketed jointly with those of another company. Depending on the case, the focus can be cooperating in distribution, product development or communication. We can differentiate co-marketing from sponsorship because the various partners play a more active role in comarketing than in sponsorship, where they are simply 
Table 2. Sponsorship incomes versus expenditure in public and private Iranian football clubs.

\begin{tabular}{|c|c|c|c|c|}
\hline Final rank & Team & Sponsorship income $(\mathrm{k} \$)$ & Expenditure $(\mathrm{k} \$)$ & Dominant sponsors \\
\hline 1 & Esteghlal & 1000 & $7-8,000$ & Bazaar-e- Mobl (from $8^{\text {th }}$ week) for $500 \mathrm{k} \$$, Bazar Mobile Iran, $500 \mathrm{k} \$$ \\
\hline 5 & Persepolis & 1,5 (reduced from $3,000 \mathrm{k} \$$ ) & 8,000 & Mary Brown (from $6^{\text {th }}$ week) \\
\hline 7 & Foolad & $200,000 \$$ & 5,000 & Foolad Khuzestan \\
\hline 9 & Sepasi & 25 & 4,000 & 1. Tabarok (2 matches: 25 million) 2. Mehr Financial institue \\
\hline 12 & Pas Hamedan & $\begin{array}{l}150 \text { (Could up to } 500 \mathrm{k \$} \text { ) to } 25 \\
\text { from Tabarrok for } 1 \text { match }\end{array}$ & Unavailable & Bic (for 8 weeks) \\
\hline 13 & Malavan* & Unavailable & Unavailable & $\begin{array}{l}\text { "Naval Force" as the owner of the club and "Anzali Free zone" from } \\
\text { middle of the season }\end{array}$ \\
\hline 14 & Esteghlal Ahwaz & 200 & 6,500 & Samsung \\
\hline 15 & Aboomoslem & Unavailable & 4,000 & 1.Tabarok (for a few match) \\
\hline 16 & Payam & Unavailable & 1,500 & - \\
\hline 17 & Pegah (Damash) ${ }^{\star *}$ & Unavailable & Unavailable & $\begin{array}{l}\text { Pegah diary as the owner of the club and then Damash from middle of } \\
\text { the season }\end{array}$ \\
\hline 18 & Bargh Shiraz & 200 & 1,800 & Samsung \\
\hline
\end{tabular}

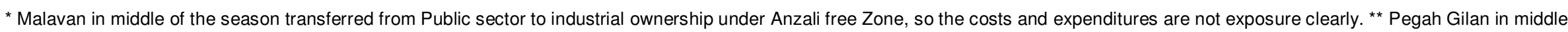
of the season transferred to private owner and changed from industrial to private, so there is no reliable statistics about incomes and expenditure.

financial contributors.

\section{Definition and benefits}

The term 'co-marketing' describes the process by which two or more subjects (public or private), one of which is at least strictly identifiable as being part of a sports organization, develop planned, organized or controlled marketing activities in order to achieve marketing objectives (which may be common or specific, but are mutually compatible) through the satisfaction of the customers (Shilbury et al., 1998). Based on the aforementioned definition, we can differentiated co-marketing from sponsorship by the fact that the various partners play a more active role in comarketing rather than simply providing financial support, as in sponsorship. Now we can estimate the significance of co-marketing in football management and usefulness of that in the context of inefficient club management like Iran. The solution fixes some major problems:

First; a club to be successful should give more to its consumers and fans. This requires human, financial, technical and relational investments, which often cannot be offered by a single club, especially in Iran scale. Co-marketing let the club to use experience and resources of commercial company or technical sponsor to give more to consumers. Second; co-marketing generate chance to exploit the opportunities in other markets. Using this solution football club will gain profit from an unrelated market, using its brand advantage, with little risk. Third and finally; interesting aspect of co-marketing is broader marketing areas in which it can be applied. Leading actors in co-marketing are equipment and clothing producers, sponsors, commercial partners, agencies and companies involved with insurance, finance, transportation, food, tourism, assistance, etc.

The risks related to collaboration are increased when the partners come from different industries or cultural backgrounds; however, the results from 
such a partnership can be much better than those achieved by companies that have similar profiles. This is why it is often worth taking such a risk. Finally, in this context, the central role of the human factor in successful cooperation and also in football co-marketing must be emphasized.

Consequently, organizations such as universities, other educational organizations and research agencies become crucial players that must somehow stimulate enrichment and cultural learning in an innovative way.

\section{The requirements for co-marketing}

There are five essential elements which should be passed for a successful co-marketing alliance. These elements are as follows:

Strategic compatibility: Shamdasani and Sheth (1995) define strategic compatibility as "the extent to which an alliance partner has complementary goals and shares similar orientations that facilitate co-ordination of alliance activities and execution of alliance strategies" (Shamdasani and Sheth, 1995). Sponsors' interpretations of strategic compatibility were more in line with the sort of expectations commonly associated with strategic alliances. For example, they sought synergistic activity, including dual planning and resource input (including financial resources), as part of the activation process.

Long-term relationships with sponsors are possible if both parties concede the need to contribute from top to bottom, and from the strategic through to the operational activities. Investment in the relationship is a key part of this and stimulates a number of beneficial flow on effects. It motivates parties to work together, it directly promotes our brand and impacts favorably on sponsor attitude toward activation, and toward viewing us in a positive light come contract renegotiation time.

Goal convergence: Simply and obviously, both party should have a goal convergence and target unit aim. The goal convergence cause utilization of tools and resources direct to the same objective and prevent from waste of rare and valuable resources.

Commitment: Commitment was defined as "a willingness by the parties involved in the sponsorship relationship to make short-term investments with the expectation of realizing long-term benefits from the relationship" (Farrelly and Quester, 2003).

It is now accepted wisdom that companies must activate sponsorship through complimentary marketing activity in order to achieve any real degree of success, and activation has been found to be strong indication of a firm's commitment to the sponsorship relationship (Farrelly and Quester, 2003).

Trust: It seems that most failures in sponsorship in Iran are due to lack of trust. Some sponsorship contracts results juridical cases, which means worst situation for a contract. In our data analysis from sponsors in season 2008 to 2009 saw that many sponsorship contracts do not yield consensus fund. Trust is a very critical factor which results to failure if it does not exist in co-marketing.

Economic and non-economic satisfaction: Research suggests that two distinct forms of satisfaction exist: one focusing on economic evaluation, the other on the outcome of interpersonal exchange. Economic satisfaction is defined as "a channel member's evaluation of the economic outcomes that flow from the relationship with its partner such as sales volume, margins and discounts" (Geyskens and Kumar, 1999).

Being able to build brand loyalty and sales through jointly organized media activity and retail promotions provides a great sense of satisfaction, but both parties can always do better, especially given the growing presence of each brand in the marketplace.

\section{DISCUSSION}

Evolution of Iranian Football to professional status requires implementation of updated football management knowledge. The most important problem faced with Iranian clubs in all series is financial straits. To face with this challenge using marketing knowledge can help clubs to use their potential for create revenue and increase their profitability. Attending to innumerous fans supporting some Iranian clubs and mentioning the popularity of clubs in their province and local, finding a way to exploiting this high potential is critical for club management. Comarketing is one of solutions best fit to Iranian clubs to enter synergy to their interactions by Sponsors. The main benefit of co-marketing is serious entrance of club to real market by offering product/services to the consumers, and lead for its fans supports against other competitive offerings.

\section{REFERENCES}

Bucklin L, Sengupta S (1993). Organizing successful co-marketing alliances. J. Mark., pp. 32-46.

Callejo MB, Forcadell FJ (2006). Real Madrid Football Club: A New Model of Business Organization for Sports Clubs in Spain. Global Business and Organizational Excellence, November/December, pp. 51-64.

Cherubini S (2007). Co-marketing: A new challenge for football managers in: Marketing and football, an international perspective (ed. Michael Desbordes), Elsevier, first edition. pp. 108-129.

Farrelly F, Quester P (2003). The effects of market orientation on trust and commitment: The case of the sponsorship business-to-business relationship. Eur. J. Mark., 37(3/4): 530-539.

Farrelly F, Quester P (2005). Investigating large-scale sponsorship relationships as co-marketing alliances. Bus. Horiz., 48: 55-62.

Geyskens I, Steenkamp JB, Kumar N (1999). A meta analysis of satisfaction in marketing channel relationships. J. Mark. Res., 36(2): 223-238. 
Shamdasani P, Sheth J (1995). An experimental approach to investigating satisfaction and continuity in marketing alliances. Eur. J. Mark., 29(4): 18-24.

Shilbury D, Quick S, Westerbeek Hans (1998). Strategic Sport Marketing. Allen and Unwin Publications.
Varadarajan R, Cunningham M (1995). Strategic alliances: A synthesis of conceptual foundations. J. Acad. Mark. Sci., 23(4): 282-296. 